Portland State University

PDXScholar

Speech and Hearing Sciences Faculty

Publications and Presentations

Speech and Hearing Sciences

2013

\title{
Syllabic Patterns in the Early Vocalizations of Quichua Children
}

\author{
Christina E. Gildersleeve-Neumann \\ Portland State University, cegn@pdx.edu \\ Barbara L. Davis \\ University of Texas at Austin \\ Peter F. Macneilage \\ University of Texas at Austin
}

Follow this and additional works at: https://pdxscholar.library.pdx.edu/sphr_fac

Part of the Other Languages, Societies, and Cultures Commons, and the Speech and Hearing Science Commons

Let us know how access to this document benefits you.

\section{Citation Details}

Gildersleeve-Neumann, C. E., Davis, B. L., \& Macneilage, P. F. (2013). Syllabic Patterns in the Early Vocalizations of Quichua Children. Applied Psycholinguistics, 34(1), 111-134.

This Article is brought to you for free and open access. It has been accepted for inclusion in Speech and Hearing Sciences Faculty Publications and Presentations by an authorized administrator of PDXScholar. Please contact us if we can make this document more accessible: pdxscholar@pdx.edu. 


\title{
Syllabic patterns in the early vocalizations of Quichua children
}

\author{
CHRISTINA E. GILDERSLEEVE-NEUMANN \\ Portland State University \\ BARBARA L. DAVIS and PETER F. MACNEILAGE \\ University of Texas at Austin
}

Received: January 27, $2010 \quad$ Accepted for publication: February 16, 2011

\begin{abstract}
ADDRESS FOR CORRESPONDENCE
Christina Gildersleeve-Neumann, Speech and Hearing Sciences Department, P.O. Box 751,

Portland State University, Portland, OR 97207-0751. E-mail: cegn@ @dx.edu
\end{abstract}

\begin{abstract}
To understand the interactions between production patterns common to children regardless of language environment and the early appearance of production effects based on perceptual learning from the ambient language requires the study of languages with diverse phonological properties. Few studies have evaluated early phonological acquisition patterns of children in non-Indo-European language environments. In the current study, across- and within-syllable consonant-vowel co-occurrence patterns in babbling were analyzed for a 6-month period for seven Ecuadorean Quichua learning children who were between 9 and 17 months of age at study onset. Their babbling utterances were compared to the babbling of six English-learning children between 9 and 22 months of age. Child patterns for both languages were compared with Quichua and English ambient language patterns. Babbling output was highly similar for the child groups: Quichua and English children's babbling demonstrated similar predicted within-syllable (coronal-front vowel, labial-central vowel, dorsal-back vowel) patterns, and across-syllable manner variegation patterns for consonants. These patterns were observed at significantly greater rates in the child groups than in the respective adult language input patterns, suggesting production system influences common to children across languages rather than ambient language perceptual learning effects during these children's babbling period.
\end{abstract}

Central issues for understanding the nature of speech acquisition concern the generality of initial speech-like patterns in children in diverse ambient language environments as well as the timing of earliest appearance of ambient language phonological properties in children's utterances. Appearance of precise production properties specific to their ambient language provide evidence of children's marshalling of perceptual learning capacities in reproducing the phonological patterns they hear. Research on the effects of ambient language patterns on children's speech production holds importance for explaining not only how children acquire language but why the sounds and sound combinations of the world's languages vary as well.

(c) Cambridge University Press 2011 0142-7164/11 \$15.00 
The acquisition of rhythmic vocalization patterns begins with a limited repertoire of simple syllable-like forms, at the beginning of the canonical babbling stage around 7 months of age (Davis \& MacNeilage, 1995; Oller, 2000). Children continue to employ those syllable patterns over a number of months (Davis, MacNeilage, \& Matyear, 2002; Kern, Davis, \& Zink, 2009; Vihman, Ferguson, \& Elbert, 1986). By 8 to 10 months of age, children demonstrate attention to and learning from perceptual properties specific to utterances in their ambient languages (e.g., Saffran, Aslin, \& Newport, 1996). However, evidence of these sophisticated language-specific perceptual capacities is not observed in children's speech output until as late as 4 to 5 years of age for later-developing sounds (Acevedo, 1993; Porter \& Hodson, 2001; Smit, Hand, Frelinger, Bernthal, \& Byrd, 1990).

Many studies of early vocal development have focused on children in English and Indo-European languages (e. g., Boysson-Bardies \& Vihman, 1991; Davis et al., 2002; Kent \& Bauer, 1985; Kern et al, 2009; Menard, Schwartz, Boe, \& Abin, 2006; Vihman et al, 1986). To date, acquisition of phonology has been studied in few non-Indo-European language environments. Available studies include Yoruba (Boysson-Bardies, 1993), Mandarin (Chen \& Kent, 2005), and Korean (Lee, Davis, $\&$ MacNeilage, 2007, 2009). To comprehensively test a generality hypothesis for early vocalization patterns in young children, studies of diverse languages are needed. Ecuadorean Quichua, spoken by indigenous speakers in Highland Ecuador, presents an opportunity to both better understand Quichua and to test the generality of early speechlike rhythmic patterns in human children within a little-studied language environment.

\section{EARLY SERIAL PATTERNS}

\section{Within-syllable patterns}

At the level of phonotactic patterning, the consonant-vowel (CV) syllable is considered to be a fundamental level of structure in the phonological systems of the world's languages (MacNeilage \& Davis, 2000; Maddieson, 1984). Rhythmic CV syllables also form a prominent aspect of children's vocal output in earliest phonological acquisition from the beginning of canonical babbling (Nathani, Ertmer, \& Stark, 2006). Babbled utterances tend to consist of one or more iterations of a CV sequence (Stoel-Gammon, 1985). Sequences of CV forms include both reduplicated (i.e., CVCV, "baba") and variegated sequences (i.e., CVCV, "bæwi;" Mitchell \& Kent, 1990). Vowel-initial utterances, consonant clusters, and utterance-final consonants have been shown to be relatively rare in studies of children from English (Jakielski, 1998; MacNeilage \& Davis, 1999; Redford, MacNeilage \& Davis, 1997) and a variety of language backgrounds (Kern \& Davis, 2009; Locke, 1983; Oller \& Eilers, 1982).

Accumulating evidence suggests a robust level of consistency in infant rhythmic syllablelike vocalizations at the onset of canonical babbling. Three preferences for consonant and vowel co-occurrences within canonical syllables have been widely observed (Chen \& Kent, 2005; Davis \& MacNeilage, 1994, 1995; Kern et al., 2009; Lee et al., 2007; Oller \& Steffans, 1993). These regularities include coronal consonants with front vowels (e.g., [i, I, ع, æ]), labial consonants with 
central vowels (e.g., [ə, $\Lambda, \mathrm{a}]$ ), and dorsal consonants with back vowels (e.g., [u, $U, a]$ ). Based on higher than chance occurrence of these CV patterns, MacNeilage and Davis (1990) proposed the "frames, then content" hypothesis. The central principle underlying this hypothesis is that observable speechlike vocalizations are based on the rhythmic jaw cycle. Little independent movement of other active articulators (e.g., tongue and velum) in canonical vocalizations is available to the infant production system in this early period of development. Open phases of the jaw cycle produce a listener percept of a vowel and close phases produce a consonant percept. Davis and MacNeilage (1990) have argued that the two lingual co-occurrence patterns (i.e., coronal with front vowels and dorsal with back vowels) are based on lack of active tongue movement independent of the rhythmic jaw cycle within CVs. The central vowel co-occurrence with labials results primarily from the tongue remaining in its resting position within syllables after being neutral in the lip closure portion of the rhythmic jaw cycle. MacNeilage and Davis (1990) predicted that these patterns are a result of inherent productionsystem capacities for accomplishing speechlike output, and consequently might be general in babbling and first word forms. Patterns in this early period have been termed "frame dominance," to refer to the general principle of rhythmic jaw movement as providing the production system "frame" for perceptually apparent rhythmic syllable output in this early period of acquisition of the phonological system (Dolata, Davis, \& MacNeilage, 2008).

Early case studies of the babbling period confirmed predictions of the frames then content hypothesis for within-syllable patterns (Davis \& MacNeilage, 1990, 1994). In a subsequent large scale study of 6659 syllables produced by six children in an English language environment in the babbling stage, Davis and MacNeilage (1995) analyzed spontaneous vocalization data to assess the presence of the three predicted patterns. Mean ratios of observed to expected frequencies were labialcentral, 1.34; coronal-front, 1.28; and dorsal-back, 1.22. Thus, on average, these three patterns occurred about $30 \%$ more often than would have been expected by chance.

A perceptual/transcription study of English-learning children's productions has provided partial support for the frame dominance hypothesis. Oller and Steffans (1993) transcribed CV co-occurrences in babbling and first words of four children. Between 10 and 12 months of age, dorsal consonants were produced most often with back vowels; both labial and coronal consonants occurred most frequently with front vowels (vowels were divided into front and back categories, no central category was analyzed). From 10 to 16 months of age, the children continued to demonstrate higher frequencies of the three predicted CV co-occurrence patterns consistent with frame dominance in first words and concurrent babbling. From 16 to 24 months of age, CV co-occurrence constraints were weaker, with labials, coronals, and dorsals occurring most often with front vowels.

Support for individual predictions from the frame dominance hypothesis has been found in some cross-language studies. Lee et al. (2007) examined CV cooccurrence patterns in the babbling of 6 children learning Korean. They found the three predicted coronal-front, labial-central, and dorsal-back patterns in all 6 children during the entire period. Vihman (1992) compiled data from three studies at 4-, 15-, and 25-word points for 10 American, 5 French, 4 Japanese, and 4 
Swedish children. Both labial-central and dorsal-back co-occurrences were observed. Zmarich and Lanni (1999) studied CV co-occurrence patterns in babbling and first words of 1 Italian child from 10 to 16 months. Using transcription and acoustic analyses, they found two of the three predicted CV co-occurrence patterns from 10 to 12 and 14 to 16 months of age: labial consonants with central vowels and coronal consonants with front vowels. Dorsal consonants occurred most often with central vowels from 10 to 12 months, and with front vowels from 14 to 16 months of age in their data. Chen and Kent (2005) examined CV co-occurrences in babbling of 24 Taiwanese children exposed to Mandarin between the ages of 0 years, 6 months $(0 ; 6)$ and $1 ; 6$. They found significant levels of CV co-occurrences for coronal-front vowel and dorsal-back vowel syllables.

A few cross-language differences in $\mathrm{CV}$ co-occurrence patterns have been noted; however, these differences have tended to be related to diverse methodologies. Some differing interpretations have resulted from categorizations of low vowels. In Vihman's (1992) study of words in English, Japanese, French, and Swedish, she did not find coronal consonant, front vowel co-occurrences. Vihman analyzed [æ] as a central vowel, complicating comparison of results with other studies (e.g., Davis \& MacNeilage, 1994, 1995) where [ae] was classified as a front vowel. Although Chen and Kent (2005) found many CV co-occurrence patterns in the babbling of Taiwanese children, they did not find the predicted labial-central vowel co-occurrence; instead, they noted a significant labial-low back vowel cooccurrence. They classified the highly frequent [a] of Mandarin children as a back vowel "to differentiate it from the resting position of the central vowel ///" (p. 524), making it difficult to relate their work to the consensus in other studies that consistently show that low back vowels occur relatively rarely in babbling and early words (Davis \& MacNeilage, 1995; Kent \& Bauer, 1985). The consideration of the [a] of Mandarin as a back vowel might have contributed to the higher than usual occurrence of labial-back vowel co-occurrences.

\section{Across-syllable patterns}

Across-syllable patterns are of interest in evaluation of the generality of sequential vocalization patterns in young children across languages. In children's characteristic reduplicative mode (i.e., "bababa"), $\mathrm{CV}$ co-occurrence patterns are by definition the same for all of the constituent syllables in an utterance. Within-syllable CV co-occurrence patterns should then be repeated across the utterance in reduplicated vocalization sequences, indicating a tendency for active tongue movement to be absent. However, children also produce across-syllable variegation in which consonants and/or vowels change within an utterance (i.e., "bawa" or "dædi"). Another aspect of the frame dominance proposal (Davis \& MacNeilage, 1995) is the prediction that most of the consonant/vowel changes perceived within these early variegated forms may also be due to the mandible rather than the tongue movement in sequences longer than CV. Most vowel to vowel variegation is predicted to be in the vowel height dimension, presumably as a result of variation in the amplitude of successive mandibular depression movements (i.e., "dædi"). Similarly, most consonant to consonant variegation is predicted to be in manner 
of articulation (degree of vocal tract constriction), also a result of variation in the amplitude of successive mandibular elevation movements (i.e., "bawa").

Predictions regarding consonant to consonant variegation patterns have been confirmed in an English language environment through evaluation of utterances involving stops, nasals, and glides in both babbling (Davis \& MacNeilage, 1995) and first words (Davis et al., 2002). In addition, Gildersleeve-Neumann, Davis, and MacNeilage (2000) confirmed this prediction in episodes involving later developing consonants that occur at low frequencies in babbling: fricatives, affricates, and liquids. In the only other test of this prediction, Lee et al. (2009) found greater height than backness variegation in vowels, but did not confirm the manner: place variegation consonant hypothesis for Korean-learning children during canonical babbling.

\section{AMBIENT LANGUAGE EFFECTS}

In contrast to the emphasis on production system influences, a major role for the influence of ambient language input on child vocalization output in the late babbling/early word period (10-12 months) has also been asserted. These effects are shown most clearly in vowel properties. Rvachew, Alhaidary, Mattock, and Polka (2008) compared vowel productions of Canadian-English and CanadianFrench children between 8 and 18 months of age. They noted increased languagespecific acoustic properties of corner vowels, suggesting increasing speech motor control during this period.

Boysson-Bardies (1993) suggested that CV co-occurrence patterns reflect ambient language patterns in babbling. She analyzed CV co-occurrences in disyllabic forms of five 10-month-old children each in French, American English, Swedish, and Yoruba language environments. Labial-central vowel associations were found in French, Swedish, and Yoruba children in the second syllable. Coronal-front vowel associations were found in French, English, and Swedish in the first syllable and in English in the second syllable. No associations of back vowels with dorsal consonants were found. In contrast to frame dominance predictions suggesting a primary role for production system influences, Boysson-Bardies (1993) found several effects that she considered to reflect ambient language input factors. Children in an American English environment favored front vowels with labial consonants, French children favored back vowels with coronals, Swedish children favored central vowels with coronals, and English and Swedish children favored central vowels with dorsal consonants. However, the overall size of the database and the number of observations in each individual syllable combination were not given. First and second syllables were analyzed separately, decreasing the sample sizes for individual analyses. No tests of statistical significance were described. Furthermore, ambient language tendencies were defined in terms of target patterns of the words children produced. It is possible that the subset of words attempted by children may show strong lexical selection effects. It has not been established that the patterns of the favored words children produce reflect adult ambient language patterns validly.

The work of Boysson-Bardies (1993) raises the important question of whether sequence patterns might be influenced by properties of the ambient language, even 
in the canonical babbling stage. Ambient language effects are most commonly evaluated by tabulating relative frequencies of various dimensions of ambient language phonology (e.g., phoneme inventories and serial organization patterns) from dictionary counts (e.g., MacNeilage, Davis, Kinney, \& Matyear, 2000) and comparing those frequencies with child inventories. Although dictionary counts provide indirect frequency of co-occurrence patterns in individual words, the actual frequency with which a child hears these patterns is more likely to be reflected in conversational samples. Lee, Davis, and MacNeilage (2008) found different cooccurrence frequencies in a comparison of dictionary counts and adult-directed speech samples. Accordingly, in the current study conversational speech samples were collected from Quichua and English adults for evaluation of ambient language properties available to children for learning from input regularities to reflect the relative frequencies in input that are typically available to young children.

\section{Quichua}

The Quechua language family is spoken by between 6 and 8 million indigenous peoples in the Andes of South America. Quichua (also termed Kichwa) is the common name for the Quechua language spoken in Ecuador. Quichua belongs to the Northern Quechua language group, Quechua II (Torero, 1983). Geographical and cultural separation of communities has led to many Quechua dialects throughout Perú, Ecuador, Argentina, Colombia, and Bolivia (Torero, 1983), and to many dialects within Ecuador. Phonological properties of Quichua differ between neighboring communities (Orr, 1978). Few studies of the phonology of Ecuadorean Quichua are available (Cerrón-Palomino, 1987; Garcés, 1996; Masaquiza \& Marlett, 2008; Moya, 1987). There are no studies of Quichua speech acquisition.

The data for this study were gathered in the central highlands of Ecuador where Quichua is spoken (Garcés, 1996; Lombeida-Naranjo, 1976; Moya, 1987; Torero, 1972). Quichua vowel phonemes are /i, a, u/. The vowels [e] and [o] are produced as allophones of /i/ and /u/ respectively, particularly in words borrowed from Spanish (Masaquiza \& Marlett, 2008). Quichua consonant phonemes are $/ \mathrm{p}, \mathrm{m}, \mathrm{w}, \mathrm{t}, \mathrm{r}, \mathrm{n}, \mathrm{j}, \mathrm{l}, \mathrm{s}, \mathrm{ts}, \mathrm{z}, \int, \mathrm{t}, \mathrm{3}, \mathrm{k} /$. Voiced unaspirated stops $[\mathrm{b}, \mathrm{d}, \mathrm{g}]$, voiced fricatives $[\beta, \gamma, \delta]$, voiceless aspirated stops $\left[\mathrm{p}^{\mathrm{h}}, \mathrm{t}^{\mathrm{h}}, \mathrm{k}^{\mathrm{h}}\right]$, and occasionally the voiceless ejectives $\left[\mathrm{p}^{\prime}, \mathrm{t}^{\prime}, \mathrm{k}^{\prime}\right]$ are regularly produced as allophones of the voiceless unaspirated stops. Frequently, [x, y] are produced as allophonic variants of $/ \mathrm{k} /$, and [ $\mathrm{\eta}]$ is often produced instead of $/ \mathrm{n} /$ word-finally. Preliminary analysis of Quichua suggested a higher frequency of dorsal consonants than in English. Words in Quichua are primarily multisyllabic, unlike the predominance of monosyllabic words in English (Maddieson, 1984).

\section{HYPOTHESES}

The goal of this study was to consider the role of production system characteristics common to children across languages studied to date, relative to appearance of perceptual influences based on input from the ambient language. Within-syllable $\mathrm{CV}$ co-occurrence patterns in babbling and first words of Quichua children were 
compared with patterns described for English-learning children and language characteristics for English adults and for Quichua adults. The relative frequency of CV co-occurrences in the children compared with adult samples was used to assess the role of production effects versus perceptual influences from the ambient language. In addition, $\mathrm{CC}$ and $\mathrm{VV}$ variegation across-syllable patterns were analyzed. The following hypotheses were tested, based on frame dominance (MacNeilage \& Davis, 1990) predictions:

1. Quichua children will be similar to English-learning children in within-syllable $\mathrm{CV}$ production patterns in prelinguistic vocalizations. CV patterns will be composed of a significantly higher frequency of labial-central, coronal-front, and dorsal-back combinations, as predicted by the frames then content hypothesis.

2. Quichua- and English-learning children will produce similar types of acrosssyllable CVCV variegation patterns. Patterns will consist of a greater percentage of (a) vowel height (than backness) changes, and (b) consonant manner (than place) changes.

\section{METHOD}

\section{Participants}

Children. Seven Quichua children participated. These children were developing normally and were described as being in the prelinguistic stage of speech acquisition at the beginning of the study, according to parental report and researcher observation. All had normal hearing based on sound field hearing testing conducted by the first author. To ensure continued normal development, hearing, speech, and language were informally monitored throughout data collection.

Six English-learning children raised in monolingual American English homes provided the comparison data (for a more complete description of these children, see Davis \& MacNeilage, 1995). All English-learning children were also reported to be typically developing and had normal hearing. Many of the English-learning children participated in a longitudinal study conducted from the age of $7 ; 2$; the data from these English-learning children was included to match the age range of the Quichua child data. Table 1 shows gender, age range, number of sessions included, and number of utterances analyzed for each child participant by language group.

Adults. Seven Quichua-speaking adults and seven English-speaking adults participated. The Quichua adults were the mothers of the seven Quichua-learning children in this study. The English adults all spoke Standard American English; five were female and two were male. All reported no history of speech, language, or hearing problems.

\section{Data collection}

Data collection took place in Ecuador during a 6-month time period. The first author spent a year in Ecuador; however, the first 6 months were spent locating the current monolingual Quichua community in this study, developing a 
Gildersleeve-Neumann et al.: Syllabic patterns in Quichua children

Table 1. Child characteristics by language environment

\begin{tabular}{llccccc}
\hline \hline Child & Language & Gender & $\begin{array}{c}\text { No. of } \\
\text { Sessions }\end{array}$ & $\begin{array}{c}\text { No. of } \\
\text { Utterances }\end{array}$ & $\begin{array}{c}\text { Initial Age } \\
\text { (months) }\end{array}$ & $\begin{array}{c}\text { Final Age } \\
\text { (month) }\end{array}$ \\
\hline QD & Quichua & $\mathrm{F}$ & 7 & 1,395 & 15 & 19 \\
QE & Quichua & $\mathrm{M}$ & 8 & 2,000 & 9 & 14 \\
QF & Quichua & $\mathrm{M}$ & 8 & 2,053 & 15 & 20 \\
QL & Quichua & $\mathrm{F}$ & 8 & 793 & 15 & 20 \\
QM & Quichua & $\mathrm{F}$ & 8 & 1,176 & 9 & 14 \\
QR & Quichua & $\mathrm{F}$ & 7 & 1,556 & 13 & 18 \\
QS & Quichua & $\mathrm{M}$ & 7 & 1,349 & 17 & 22 \\
EC & English & $\mathrm{F}$ & 20 & 3,093 & 9 & 15 \\
EN & English & $\mathrm{M}$ & 37 & 1,651 & 9 & 22 \\
EP & English & $\mathrm{M}$ & 38 & 1,389 & 9 & 22 \\
ER & English & $\mathrm{F}$ & 35 & 3,011 & 9 & 22 \\
ES & English & $\mathrm{F}$ & 20 & 1,878 & 9 & 21 \\
EW & English & $\mathrm{M}$ & 17 & 2,031 & 9 & 15 \\
\hline \hline
\end{tabular}

relationship with the adults in the community, and locating families with children in the babbling age range. Quichua child and adult samples were collected in a remote community located in the Andean highlands, consisting of approximately 600 people who speak Quichua as their first language. Approximately $83 \%$ of the adult males and $10 \%$ of the adult females spoke limited Spanish (Hess, 1992). The community is remarkably isolated, requiring $2 \mathrm{hr}$ of travel by foot from the closest village, which is a 2-hr bus ride from the closest town of 20,000. Many community members, particularly the women, had never been further than a 2-hr walking radius of their home. Most adults and almost all of the women had not attended school and were illiterate. This isolation from others and from standardized schooling resulted in little influence of Spanish in the speech development of the Quichua children studied.

The first author collected the Quichua child data with a research assistant, a native Quichua speaker, who was a teacher in that Quichua community. Each Quichua child was observed, audio recorded, and transcribed by the first author. Children were recorded approximately every 3 weeks for $1 \mathrm{hr}$. The first author spent 2 to $4 \mathrm{hr}$ with each family for each session. Seven to eight sessions were obtained for each child. Data collection took place in the children's homes most of the time, although one session for each child was conducted in a community meeting room. Children interacted normally with anyone present: typically the mother, family members, the first author, and her research assistant. The environment was kept as natural as possible.

For each Quichua and American English adult samples, structured conversational interviews were collected. Seventy-five utterances from each adult speaker were selected and transcribed. To lessen the likelihood of frequently occurring words predominating, utterances selected were longer descriptive utterances.

The American children were audio-recorded on a weekly basis from the onset of babbling through the emergence of first words. From 12 to 22 months of age, children were audiotaped on a biweekly basis. All data collection for the 
American English-learning children took place in their homes in natural play interactions.

All Quichua and English adult data was collected using a Marantz PMD-201 portable analog tape recorder with a receiver. The adults also used the transmitter and receiver as well as a Sony wireless microphone to ensure sound fidelity for transcription.

For child data collection, an Audio-Technica Pro 88W/R wireless microphone was clipped to each participating child's clothing to maximize clear acoustic signals. The corresponding wireless transmitter was placed in a small pack on the child's back.

\section{Data analysis}

Transcription. Child and adult data were phonetically transcribed. Child transcription included diacritics for child speech, including vowel lengthening, rounding, syllabification, palatalization, and velarization (Bush et al., 1973). Only comfort state vocalizations containing words or canonical babbling vocalizations were analyzed. Vocalizations such as grunts, cries, squeals, raspberries, and whispers were not analyzed. Utterance beginnings and ends were determined perceptually by the transcriber by a period of silence on both margins (Davis \& MacNeilage, 1995; Oller \& Lynch, 1992).

Initial analysis included words produced during the data collection period. Words were defined by researcher judgment, using criteria outlined by Vihman and McCune (1994). These criteria included information on determinative context, parental identification, phonetic shape, and relationship of the token to the child's other tokens. Parent report also aided in determining words. It proved difficult to define words for Quichua children: absence of cultural emphasis on word identification in children by adults or others in the social context, absence of research on typical first words, and the first author's basic Quichua level were complicating factors. Utterances were defined as "words" only when there was no doubt on agreement about their meaning in the communicative context based on agreement between the first author and parents or other adults. Because of the limited data on words during the data collection time period it was decided to compare babbling utterances only.

The first author transcribed Quichua child and adult data as well as English adult data. She is trilingual (English, German, Spanish) and has basic spoken and higher level academic skills in Quichua and French. Transcribed child and adult data were entered into and analyzed with software provided by Logical International Phonetic Programs, 2.02 (Oller \& Delgado, 2000). Analyses included within-syllable CV co-occurrence patterns and across-syllable reduplication and variegation patterns.

Transcription analysis. Individual child and child language group data were analyzed so that individual child differences could be distinguished from language group trends. Fifty-three hour-long sessions for Quichua children and 167 hourlong sessions for American English children were analyzed. As noted above, babbling and word data were both analyzed initially. However, out of the total 10,322 Quichua utterances, only 208 were defined as words. Only two children, 
Gildersleeve-Neumann et al.: Syllabic patterns in Quichua children

Table 2. Total syllables and words produced by Quichua- $(Q)$ and English-speaking adults (E) by individual and by language group

\begin{tabular}{|c|c|c|c|c|c|}
\hline \multicolumn{3}{|c|}{ Quichua-Speaking Adults } & \multicolumn{3}{|c|}{ English-Speaking Adults } \\
\hline \multirow[b]{2}{*}{ Participant } & \multicolumn{2}{|c|}{ Total No. of } & \multirow[b]{2}{*}{ Participant } & \multicolumn{2}{|c|}{ Total No. of } \\
\hline & Syllables & Words & & Syllables & Words \\
\hline Q1 & 1,635 & 595 & E1 & 1,444 & 1,111 \\
\hline Q2 & 1,769 & 722 & E2 & 1,574 & 1,138 \\
\hline Q3 & 1,803 & 824 & E3 & 1,615 & 1,184 \\
\hline Q4 & 1,474 & 618 & E4 & 1,486 & 1,070 \\
\hline Q5 & 1,761 & 676 & E5 & 1,320 & 1,019 \\
\hline Q6 & 1,451 & 619 & E6 & 1,972 & 1,405 \\
\hline Q7 & 1,786 & 740 & E7 & 1,632 & 1,268 \\
\hline Total & 11,679 & 4,794 & Total & 11,043 & 8,195 \\
\hline
\end{tabular}

QD and QF, produced more than 15 words total for the 6-month period; each of these two children produced 83 words during the entire time period. Because of the limited word data, further word analysis was not included. For the babbling data, CV co-occurrences were initially analyzed by division into early, middle, and late babbling ages (from 9 to 13,13 to 17 , and 17 to 22 months of age) and overall babbling frequencies. Because very few differences by babbling time period were observed, the data are presented for the entire 9- to 22-month period. When age-specific differences were found, they are presented after the babbling data totals. Table 2 shows total number of words and syllables analyzed for the seven Quichua and seven American adults.

Reliability. For Quichua child reliability, extensive effort was made to locate a fluent Quichua transcriber. Two Spanish/Quichua bilingual linguists attempted to capture vowel characteristics outside of the /i, e, a, o, u/ of Spanish. These Ecuadorean linguists and the first author determined that they were not reliable in hearing vowel properties outside the five vowel phoneme range of Spanish necessary for infant vocalization transcription. Subsequently, a trilingual English/French/Spanish phonetician with extensive training in child transcription retranscribed $10 \%$ of the Quichua children's data. Point to point agreement was calculated for each child and for the group. Total reliability averaged 66\%, ranging from $61 \%$ to $75 \%$ per child. Consonant reliability for stops, nasals, and glides averaged $81 \%$, ranging from $66 \%$ to $91 \%$. Reliability directly related to CV cooccurrences and across syllable analysis involves consonant place and manner and vowel front/ back and height dimensions. Reliability was $81 \%$ for consonant place (individual child range, $75 \%-86 \%$ ), $86 \%$ for consonant manner $(73 \%-92 \%)$, $67 \%$ for vowel backness dimension (62\%-79\%), and $73 \%$ for the vowel height dimension $(60.4 \%-79 \%)$.

Detailed explanation of the reliability for the American English children's data analyzed has been reported in previous research (Davis \& MacNeilage, 1995; 
Davis et al., 2002). Reliability calculations were consistent with procedures in this study, although all transcribers were monolingual English speakers. Stops, nasals, and glides were used to determine consonant reliability for English-learning children, which averaged $77 \%$ (range $=63-83 \%$; reliability for later developing sounds was not determined. Vowel reliability averaged $45 \%$ (range $=33-69 \%$ ). The lowest rate of vowel reliability for the English-learning children was for back vowels.

An Ecuadorean linguist who was bilingual in Quichua and Spanish conducted transcription reliability for a randomly selected $10 \%$ of Quichua adult utterances. Average total reliability was $94 \%$ and ranged from $91 \%$ to $96 \%$ by speaker. An English-speaking phonetician conducted transcription reliability for English adults. Ten percent of adult utterances were randomly selected for retranscription. Average total reliability was $97 \%$ and ranged from $95 \%$ to $99 \%$ by speaker.

Comparisons. Vowels were divided into front (including, but not limited to [i, $\mathrm{I}$, $\varepsilon, \mathrm{e}, æ])$, central $\left(\left[\Lambda, \mathrm{a}, \partial, \gamma^{\top}\right]\right)$, and back $([\cup, \mathrm{u}, \mathrm{o}, \supset, \mathrm{a}])$ for analysis of the vowel backness dimension. Vowels were divided into high ([i, I, u, u]), mid ([ع, e, ə, $\Lambda, \gamma^{\prime}$, ॰, o]), and low ([æ, a, a]) categories for the vowel height dimension. Consonants were divided by place of articulation analysis into labial (such as $[\mathrm{b}, \mathrm{p}, \mathrm{m}, \mathrm{w}, \beta$, $\Phi, \mathrm{v}, \mathrm{f}]$ ), coronal (such as [n, $\left.\mathrm{n}, \delta, \theta, \mathrm{z}, \mathrm{s}, \mathrm{d}, \mathrm{ts}, \mathrm{\jmath}, 3, \int, \mathrm{b}, \mathfrak{t}, \mathrm{l}, \mathrm{s}, \mathrm{j}, \mathrm{c}, K\right]$ ), and dorsal $([\mathrm{g}, \mathrm{k}, \mathrm{\eta}, \mathrm{x}, \mathrm{\gamma}, \mathrm{N}, \mathrm{R})$. Consonants were divided into the following manner categories for preliminary analysis: stops, nasals, glides, fricatives, affricates, liquids, trills, implosives, ejectives, and clicks. The three latter categories were extremely infrequent and were not included in the final analyses.

Within-syllable CV co-occurrence patterns for contiguous consonant place and vowel backness parameters within syllables were compared (a) between children in a language group, and (b) between adults and children within each of the two ambient languages. Because the English children's data have been evaluated elsewhere, significant within-group patterns for Quichua child data only (babbling by age group and total babbling) were determined. Weighted averages were used in all comparisons so participants were represented equally regardless of their production frequency. Syllable-initial consonants and vowels in all CVCV shapes were analyzed for consonant and vowel reduplication and variegation.

Across-syllable CC and VV patterns were analyzed for Quichua- and Englishlearning children. Variegation patterns in babbling for consonants and for vowels were compared for the two child language groups.

Statistical analyses. All data were categorical. Data were evaluated in terms of expected frequencies based on the observed productions occurring in the data samples. For CV co-occurrence patterns, the statistical significance of differences within and between groups was determined using generalized estimating equations (McCullagh \& Nelder, 1989) with two dependent variables: adult versus child and language. For child across-syllable patterns, the statistical significance of expected and observed frequencies within each child language group was determined using chi-square analysis. Cross-linguistic comparisons of child variegation patterns were made with generalized estimating equations. ${ }^{1}$ 
Gildersleeve-Neumann et al.: Syllabic patterns in Quichua children

Table 3. Observed to expected consonant-vowel co-occurrence patterns in words of Quichua and American English adults, and the babbling of Quichua and American English learning children

\begin{tabular}{lllll}
\hline \hline & & \multicolumn{3}{c}{ Consonants } \\
\cline { 3 - 5 } \multicolumn{1}{c}{ Language and Utterance Type } & Vowels & Coronal & Labial & Dorsal \\
\hline \multirow{2}{*}{ Quichua adults } & Front & $\mathbf{1 . 2 7}^{a}$ & 0.86 & 0.47 \\
& Central & 0.88 & $\mathbf{1 . 1 4}^{a}$ & $\mathbf{1 . 1 7}^{a}$ \\
& Back & 0.81 & 0.88 & $\mathbf{1 . 5 5}^{a}$ \\
American English adults & Front & $1.00^{a}$ & 1.00 & $\mathbf{1 . 0 1}$ \\
& Central & 0.99 & $0.97^{a}$ & $\mathbf{1 . 1 6}^{a}$ \\
Quichua children babbling & Back & 1.00 & $\mathbf{1 . 0 1}$ & $0.96^{a}$ \\
& Front & $\mathbf{1 . 2 1}^{a}$ & 0.76 & 0.36 \\
American English children babbling & Central & 0.81 & $\mathbf{1 . 3 6}^{a}$ & $\mathbf{1 . 3 4}^{a}$ \\
& Back & 0.73 & 0.64 & $\mathbf{2 . 8 2}^{a}$ \\
& Front & $\mathbf{1 . 2 7}^{a}$ & 0.68 & 0.91 \\
& Central & 0.80 & $\mathbf{1 . 2 8}^{a}$ & 0.91 \\
& Back & 0.79 & $\mathbf{1 . 1 1}$ & $\mathbf{1 . 5 4}^{a}$ \\
\hline \hline
\end{tabular}

Note: Bold text denotes observed co-occurrence patterns occurring at a rate greater than expected by chance.

${ }^{a}$ Predicted co-occurrences based on frame dominance production constraints.

\section{RESULTS}

\section{Within-syllable CV co-occurrence patterns}

Results for CV co-occurrence patterns are shown in Table 3 in terms of observed to expected ratios. The three $\mathrm{CV}$ co-occurrence patterns predicted by the frames then content hypothesis occurred at levels substantially above chance in Quichua babbling: $\chi^{2}(4, N=9,594)=299.48, p=.0001$. CV co-occurrence levels of the predicted patterns were similar in these children regardless of language environment, although the overall CV co-occurrence patterns differed between Quichua- and English-learning children's babbling: $\chi^{2}(4, N=35,768)=31.34$, $p=.0001$. Between-language differences in child groups likely resulted from higher than expected dorsal-central co-occurrences in Quichua children and higher than expected labial-back patterns in English-learning children.

In the adult conversational samples, only Quichua adults showed the three predicted co-occurrence patterns (see Table 3). These Quichua adult patterns were significantly different from the American English adult patterns: $\chi^{2}(4, N=$ $22,474)=68.46, p=.0001$. Both adult groups had higher than expected dorsalcentral CV co-occurrences. Compared to Quichua adults, Quichua children's babbling, $\chi^{2}(4, N=24,247)=30.5, p=.0001$, showed significantly higher levels of the predicted CV co-occurrences overall. Table 4 shows individual CV cooccurrence patterns for Quichua children in babbling. All children except for one, $\mathrm{QL}$, showed all predicted CV co-occurrence patterns at rates greater than chance. 
Gildersleeve-Neumann et al.: Syllabic patterns in Quichua children

Table 4. Observed to expected consonant-vowel co-occurrence ratios for individual Quichua- and English-learning children

\begin{tabular}{|c|c|c|c|c|c|c|c|c|}
\hline & \multirow[b]{2}{*}{ Consonants } & \multicolumn{3}{|c|}{ Vowels } & & \multicolumn{3}{|c|}{ Vowels } \\
\hline & & Front & Central & Central & & Front & Central & Back \\
\hline \multirow[t]{3}{*}{$\mathrm{QE}$} & Coronal & $1.29^{a}$ & 0.74 & 1.05 & EN & $1.14^{a}$ & 0.79 & 0.57 \\
\hline & Labial & 0.78 & $1.25^{a}$ & 0.62 & & 0.52 & $1.54^{a}$ & 0.75 \\
\hline & Dorsal & 0.44 & 1.37 & $1.69^{a}$ & & 0.68 & 2.21 & $0.87^{a}$ \\
\hline \multirow[t]{3}{*}{ QM } & Coronal & $\mathbf{1 . 0 5}^{a}$ & 0.95 & 0.90 & $\mathrm{EP}$ & $1.54^{a}$ & 0.84 & 5.52 \\
\hline & Labial & 0.57 & $1.54^{a}$ & 1.69 & & 0.86 & $0.87^{a}$ & 4.67 \\
\hline & Dorsal & 0.86 & 1.12 & $1.59^{a}$ & & 0.09 & 0.18 & $\mathbf{3 . 0 8}^{a}$ \\
\hline \multirow[t]{3}{*}{ QR } & Coronal & $0.84^{a}$ & 1.36 & 0.33 & EC & $1.00^{a}$ & 0.81 & 0.57 \\
\hline & Labial & 1.17 & $0.71^{a}$ & 1.05 & & 0.66 & $1.79^{a}$ & 1.55 \\
\hline & Dorsal & 0.52 & 1.36 & $4.31^{a}$ & & 0.60 & 0.62 & $2.31^{a}$ \\
\hline \multirow[t]{3}{*}{ QL } & Coronal & $1.18^{a}$ & 0.76 & 0.90 & ER & $2.30^{a}$ & 0.76 & 0.91 \\
\hline & Labial & 0.83 & $1.30^{a}$ & 0.56 & & 0.69 & $0.73^{a}$ & 0.58 \\
\hline & Dorsal & 0.34 & 1.67 & $3.04^{a}$ & & 2.04 & 0.80 & $1.20^{a}$ \\
\hline \multirow[t]{3}{*}{ QD } & Coronal & $1.33^{a}$ & 0.82 & 0.55 & ES & $3.66^{a}$ & 0.75 & 3.05 \\
\hline & Labial & 0.21 & $1.58^{a}$ & 1.09 & & 0.83 & $0.44^{a}$ & 0.93 \\
\hline & Dorsal & 0.31 & 1.09 & $3.80^{a}$ & & 0.73 & 0.38 & $1.23^{a}$ \\
\hline \multirow[t]{3}{*}{$\mathrm{QF}$} & Coronal & $1.37^{a}$ & 0.81 & 0.50 & EW & $2.22^{a}$ & 0.87 & 1.78 \\
\hline & Labial & 0.43 & $1.59^{a}$ & 1.07 & & 0.66 & $0.63^{a}$ & 1.92 \\
\hline & Dorsal & 0.32 & 1.21 & $2.23^{a}$ & & 0.76 & 0.47 & $0.79^{a}$ \\
\hline \multirow[t]{3}{*}{ QS } & Coronal & $1.25^{a}$ & 0.85 & 0.80 & & & & \\
\hline & Labial & 1.02 & $1.10^{a}$ & 0.63 & & & & \\
\hline & Dorsal & 0.24 & 1.40 & $1.78^{a}$ & & & & \\
\hline
\end{tabular}

Note: Bold text denotes observed co-occurrence patterns occurring at a rate greater than expected by chance.

${ }^{a}$ Predicted co-occurrences based on the frame dominance hypothesis.

Based on analysis that divided the Quichua children into three equal time periods, no significant change in the $\mathrm{CV}$ co-occurrence patterns occurred over time. There were also no differences in within-syllable CV patterns of individual Quichua children.

As shown in Table 4, if the extensive data for the English-learning children are viewed for the entire period, the predicted CV co-occurrence patterns are not seen with the same frequency as they are in the Quichua children. All Englishlearning children demonstrated the predicted coronal-front vowel co-occurrence for the total time period, two of six children produced predicted labial-front vowel patterns and four of six English-learning children produced dorsal back vowel patterns at rates higher than chance. Frequency of predicted CV cooccurrence patterns did not change for individual English-learning children during babbling. For the English-learning children, a split-half analysis was conducted of the original database (Davis \& MacNeilage, 1995); no significant change over time was reported. 


\section{Across-syllable variegation patterns}

The frequency of variegation versus reduplication was compared. The percentages of consonantal variegation in two syllable sequences were Quichua babbling, $54 \%$; English babbling $38 \%$. The percentages of vowel variegation in two syllable sequences were Quichua babbling, 47\%; English babbling, $47 \%$.

Relative frequency of consonant place versus manner variegation and vowel height versus backness dimension were analyzed. Table 5 shows observed to expected ratios for place and manner variegation and for height and backness variegation for all children in both languages in all conditions. The percentages of consonant place versus manner categories of children's total utterances were $16 \%$ place versus $4 \%$ manner for Quichua babbling and $14 \%$ place versus $7 \%$ manner for English babbling. For vowels, relative frequency of height to backness variegation was analyzed. The percentages of these height to backness variegation categories were 15\% height versus 10\% backness for Quichua babbling and 15\% height versus 10\% backness for English babbling.

In babbling sequences, predicted CC manner variegation patterns were produced at higher rates than place variegation for the total babbling period in seven out of seven Quichua and five out of six English-learning children. In the Quichua children, this preference for consonant manner variegation did not change over time; all Quichua children at each time period preferred manner to place variegation except for QM from 13 to 17 months of age. For English-learning children, consonant manner to place variegation was preferred by five of six children from 9 to 13 months of age and six of six children from 13 to 17 months of age; however, this preference declined in frequency between 17 and 22 months of age, with only one of four English-learning children preferring manner over place variegation.

The predicted preference for vowel height over backness variegation was not clearly observed in Quichua children. Only three of the seven children showed a clear preference for vowel height variegation during the total time period. Englishlearning children showed a clearer preference for vowel height over backness changes in variegated babbling. During the total time period, five of six Englishlearning children showed the height pattern.

Table 6 shows statistical results of within-language group comparisons of the frequency of variegated consonant and vowel sequences. These results indicate that both Quichua- and English-learning children produced significantly more manner than place variegation within utterances for the total babbling period.

Table 7 shows statistical results of the across-language comparison of reduplication and variegation patterns in Quichua- and English-learning children. Quichua and English children's babbling did not differ in consonant variegation patterns during the entire babbling period; both groups showing an overwhelming preference for consonant manner variegation predicted by the frames then content hypothesis. For vowel variegation, Quichua children did not show a preference for height or backness sequences; English-learning children produced significantly more predicted vowel height than vowel backness reduplication patterns. 
Table 5. Observed to expected variegation ratios in consonant-vowel-consonant-vowel sequences

\begin{tabular}{|c|c|c|c|c|c|c|c|c|c|c|c|c|c|c|c|}
\hline \multirow[b]{2}{*}{ Time Period } & & \multirow[b]{2}{*}{ Variegation Type } & \multicolumn{7}{|c|}{ Quichua Children } & \multicolumn{6}{|c|}{ English Children } \\
\hline & & & QE & QM & QR & QL & QD & QF & QS & $\mathrm{EC}$ & EN & $\mathrm{EP}$ & ER & ES & EW \\
\hline \multirow[t]{4}{*}{ 9-13 months } & \multirow[t]{2}{*}{ Consonants } & Place & 0.37 & 0.54 & $\mathrm{x}$ & NA & NA & NA & NA & 0.77 & 1.21 & 0.40 & 0.35 & 0.09 & 0.25 \\
\hline & & Manner & $1.45^{a}$ & $1.11^{a}$ & $\mathrm{x}^{a}$ & $\mathrm{NA}^{a}$ & $\mathrm{NA}^{a}$ & $\mathrm{NA}^{a}$ & $\mathrm{NA}^{a}$ & $1.32^{a}$ & $0.80^{a}$ & $1.49^{a}$ & $1.68^{a}$ & $2.19^{a}$ & $2.44^{a}$ \\
\hline & \multirow[t]{2}{*}{ Vowels } & Backness & 0.92 & 1.05 & $\mathrm{x}$ & NA & NA & NA & NA & 0.56 & 0.84 & 0.54 & 0.78 & 1.14 & 0.89 \\
\hline & & Height & $\mathbf{1 . 0 6}^{a}$ & $0.97^{a}$ & $\mathrm{x}^{a}$ & $\mathrm{NA}^{a}$ & $\mathrm{NA}^{a}$ & $\mathrm{NA}^{a}$ & $\mathrm{NA}^{a}$ & $1.38^{a}$ & $1.11^{a}$ & $1.29^{a}$ & $1.15^{a}$ & $0.83^{a}$ & $1^{1.10^{a}}$ \\
\hline \multirow[t]{4}{*}{$13-17$ months } & \multirow[t]{2}{*}{ Consonants } & Place & 0.44 & 1.11 & 0.39 & 0.33 & 0.61 & 0.24 & NA & 0.67 & 0.78 & 0.31 & 0.66 & 0.88 & 0.59 \\
\hline & & Manner & $1.52^{a}$ & $0.98^{a}$ & $1.58^{a}$ & $1.50^{a}$ & $1.09^{a}$ & $1.52^{a}$ & $\mathrm{NA}^{a}$ & $1.46^{a}$ & $1.42^{a}$ & $1.44^{a}$ & $1.40^{a}$ & $\mathbf{1 . 1 3}^{a}$ & $1.48^{a}$ \\
\hline & \multirow[t]{2}{*}{ Vowels } & Backness & 1.10 & 1.03 & 0.74 & 0.85 & 1.02 & 1.25 & NA & 0.44 & 0.71 & 1.20 & 0.72 & 1.07 & 1.02 \\
\hline & & Height & $0.87^{a}$ & $0.99^{a}$ & $1.16^{a}$ & $1.07^{a}$ & $1.00^{a}$ & $0.75^{a}$ & $\mathrm{NA}^{a}$ & $1.82^{a}$ & $\mathbf{1 . 1 9}^{a}$ & $0.86^{a}$ & $1.30^{a}$ & $0.93^{a}$ & $0.98^{a}$ \\
\hline \multirow[t]{4}{*}{ 17-22 months } & \multirow[t]{2}{*}{ Consonants } & Place & NA & NA & 0.83 & 0.77 & 0.13 & 0.38 & 0.92 & $\mathrm{NA}$ & 1.14 & 1.00 & 0.89 & 0.68 & NA \\
\hline & & Manner & $\mathrm{NA}^{a}$ & $\mathrm{NA}^{a}$ & $1.13^{a}$ & $1.18^{a}$ & $2.33^{a}$ & $1.62^{a}$ & $1.03^{a}$ & $\mathrm{NA}^{a}$ & $0.81^{a}$ & $1.00^{a}$ & $1.12^{a}$ & $1.24^{a}$ & $\mathrm{NA}^{a}$ \\
\hline & \multirow[t]{2}{*}{ Vowels } & Backness & NA & NA & 0.82 & 0.85 & 0.74 & 1.00 & 1.01 & NA & 0.76 & 1.18 & 0.99 & 0.56 & NA \\
\hline & & Height & $\mathrm{NA}^{a}$ & $\mathrm{NA}^{a}$ & $1.09^{a}$ & $1.10^{a}$ & $1.19^{a}$ & $1.00^{a}$ & $0.99^{a}$ & $\mathrm{NA}^{a}$ & $1.12^{a}$ & $0.81^{a}$ & $1.01^{a}$ & $1.24^{a}$ & $\mathrm{NA}^{a}$ \\
\hline \multirow[t]{4}{*}{ Total } & \multirow[t]{2}{*}{ Consonants } & Place & 0.41 & 0.68 & 0.68 & 0.71 & 0.15 & 0.36 & 0.92 & 0.74 & 0.92 & 0.59 & 0.56 & 0.51 & 0.39 \\
\hline & & Manner & $1.47^{a}$ & $1.07^{a}$ & $1.26^{a}$ & $1.22^{a}$ & $2.22^{a}$ & $1.60^{a}$ & $1.03^{a}$ & $1.36^{a}$ & $1.14^{a}$ & $1.28^{a}$ & $1.59^{a}$ & $1.57^{a}$ & $1.89^{a}$ \\
\hline & \multirow[t]{2}{*}{ Vowels } & Backness & 1.05 & 0.95 & 0.75 & 0.89 & 0.72 & 1.01 & 1.01 & 0.52 & 0.66 & 0.94 & 0.82 & 1.13 & 0.98 \\
\hline & & Height & $0.94^{a}$ & $\mathbf{1 . 0 3}^{a}$ & $1.15^{a}$ & $1.07^{a}$ & $1.18^{a}$ & $0.99^{a}$ & $0.99^{a}$ & $1.48^{a}$ & $1.26^{a}$ & $\mathbf{1 . 0 5}^{a}$ & $1.16^{a}$ & $0.88^{a}$ & $1.02^{a}$ \\
\hline
\end{tabular}

Note: Bold text denotes observed consonant-consonant or vowel-vowel reduplication patterns occurring at a rate greater than expected by chance. NA, no data collected at this time point; $x$, data collected at this time point did not include sufficient variegated sequences for analysis.

${ }^{a}$ Predicted co-occurrences based on the frame dominance hypothesis. 
Gildersleeve-Neumann et al.: Syllabic patterns in Quichua children

Table 6. Results of chi-square analyses of within-language group patterns for consonant-consonant and vowel-vowel variegated sequences

\begin{tabular}{lccrcc}
\hline \hline & Type & Time Period & $\chi^{2}$ & $d f$ & $p$ \\
\hline \multicolumn{5}{c}{ Manner Versus Place } \\
\hline QC & Babbling & Overall & 689.675 & 1 & .0009 \\
EC & Babbling & Overall & 38.647 & 1 & .0165 \\
\hline \multicolumn{7}{c}{ Height Versus Backness Changes } \\
\hline QC & Babbling & Overall & 4.201 & 1 & .1488 \\
EC & Babbling & Overall & 307.190 & 1 & .0021 \\
\hline \hline
\end{tabular}

Note: Analyses were conducted for Quichua-learning children (QC) and English-learning children (EC). Comparisons are the observed to expected frequency of consonant manner versus place and vowel height versus backness variegation within each language group.

\section{SUMMARY}

Predicted within-syllable patterns of labial-central, coronal-front, and dorsal-back combinations were observed in babbling for both Quichua and English-learning children. Predicted CC across-syllable patterns were also observed, with both Quichua- and English-learning children showing a preference for manner over place variegation for consonants in babbling, as predicted. Quichua children did not show a significant preference, whereas the English-learning children did show a significant preference for vowel height over backness variegation in babbling.

\section{DISCUSSION}

Frame dominance predictions for speech acquisition were confirmed for the majority of instances of within-syllable co-occurrences and across-syllable variegation patterns observed in babbling of seven Quichua children over a 6-month period. Patterns for Quichua- and English-learning children were remarkably similar. There was relatively little evidence that within-syllable patterns were being derived from ambient language input, because Quichua adults produced higher rates of within-syllable co-occurrences than were observed in English adults.

\section{Within-syllable patterns}

Quichua children produced all predicted CV co-occurrence patterns at rates greater than chance. Overall, predicted co-occurrences were observed on more than $90 \%$ of potential occasions. These findings are consistent with previous studies of English (Davis \& MacNeilage, 1995; Davis et al., 2002), and with most findings in other languages studied to date (e.g., Kern et al., 2009; Lee et al., 2007). 
Gildersleeve-Neumann et al.: Syllabic patterns in Quichua children

Table 7. Between-language group comparison of across syllable variegated consonant-consonant and vowel-vowel sequences

\begin{tabular}{|c|c|c|c|c|c|}
\hline Type & $\begin{array}{l}\text { Residual } \\
\text { Deviance }\end{array}$ & $\begin{array}{l}\text { Residual } \\
\quad d f\end{array}$ & $\begin{array}{c}\text { Mean } \\
\text { Deviance } \\
(\mathrm{Dev} / d f)\end{array}$ & $\begin{array}{c}F \\
\text { Ratio* }\end{array}$ & $p$ \\
\hline \multicolumn{6}{|c|}{ Consonant Manner Versus Place } \\
\hline \multicolumn{6}{|l|}{ 9-13 months } \\
\hline Combined QC \& EC contrast & 51.16 & 7 & 7.308 & & \\
\hline Separate QC \& EC contrast & 51.09 & 6 & 8.515 & & \\
\hline Difference & 0.07 & 1 & 0.067 & 0.01 & .9323 \\
\hline \multicolumn{6}{|l|}{$13-17$ months } \\
\hline Combined QC \& EC contrast & 12.02 & 11 & 1.093 & & \\
\hline Separate QC \& EC contrast & 10.74 & 10 & 1.074 & & \\
\hline Difference & 1.28 & 1 & 1.284 & 1.2 & .2998 \\
\hline \multicolumn{6}{|l|}{ 17-22 months } \\
\hline Combined QC \& EC contrast & 28.12 & 8 & 3.515 & & \\
\hline Separate QC \& EC contrast & 23.24 & 7 & 3.320 & & \\
\hline Difference & 4.88 & 1 & 4.884 & 1.47 & .2645 \\
\hline \multicolumn{6}{|c|}{ Vowel Height Versus Backness Dimension } \\
\hline \multicolumn{6}{|l|}{ 9-13 months } \\
\hline Combined QC \& EC contrast & 15.03 & 7 & 2.148 & & \\
\hline Separate QC \& EC contrast & 13.82 & 6 & 2.303 & & \\
\hline Difference & 1.21 & 1 & 1.212 & 0.53 & .4956 \\
\hline \multicolumn{6}{|l|}{ 13-17 months } \\
\hline Combined QC \& EC contrast & 29.47 & 11 & 2.679 & & \\
\hline Separate QC \& EC contrast & 28.25 & 10 & 2.825 & & \\
\hline Difference & 1.22 & 1 & 1.222 & 0.43 & .5255 \\
\hline \multicolumn{6}{|l|}{ 17-22 months } \\
\hline Combined QC \& EC contrast & 4.78 & 8 & 0.598 & & \\
\hline Separate QC \& EC contrast & 4.77 & 7 & 0.682 & & \\
\hline Difference & 0.01 & 1 & 0.010 & 0.01 & .9093 \\
\hline
\end{tabular}

Note: Comparisons are the observed to expected frequency of consonant manner versus place and vowel height versus backness variegation in Quichua-learning children (QC) versus English-Learning children (EC). Results are a weighted analysis of variation using general linear modeling with link $=\log$ and distribution $=$ binomial.

Results strongly indicate the fundamental status of production constraints on within-syllable serial organization of child vocalizations across diverse languages. These patterns in early development are best characterized by a lack of articulator movement independent of the jaw within syllables, consistent with predictions of frame dominance. Quichua- and English-learning children both produced the predicted $\mathrm{CV}$ co-occurrence patterns at significant levels. The major difference between the two child groups was for higher levels of predicted patterns in Quichua children. 


\section{Across-syllable variegation patterns}

The frame dominance prediction for variegation provides a unified perspective for consonants and vowels within and across syllables. Consonants and vowels are considered to be jointly subject to a single causal influence: variability in the amplitude of mandibular oscillation. Tongue movement within and across syllables is significantly less frequent. These Quichua- and English-learning children preferred consonant manner over place changes in variegated disyllabic utterances in their babbling vocalizations. These across-syllable patterns observed in both Quichua- and English-learning children suggest the dominance of rhythmic jaw movements without independent movements of active articulators during the closure phases within CVCV sequences. According to frame-content predictions, manner changes are primarily attributable to changes in the amplitude of the closing phase of mandibular oscillation across successive cycles. A preference for manner over place changes, or jaw movement without independent tongue movement within CVCV sequences, suggests that frame dominance is characteristic of these children even in variegated utterances. Variegation, on the face of it, would seem to require active across-syllable tongue movements. Babbling of Quichuaand English-learning children did not differ in across-syllable consonant variegation patterns, suggesting that this effect persists as an organizing principle for output throughout the period when children are producing prelinguistic babbling vocalizations.

Quichua children's vowel variegation patterns did not show a clear preference pattern across the study. In contrast, there was a vowel height over vowel frontback variegation preference in English-learning children's babbling overall. The lack of a predominance of changes in height versus backness in Quichua babbling was not an indirect result of an increase in the tendency to vary the height and backness dimensions simultaneously, which would be the case if there was an input effect from the ambient language. The percentage of sequences with both height and backness changes occurring together was no greater in Quichua- than in English-learning children.

\section{Ambient language input effects}

The most striking relation between these children's vocalization output patterns and input patterns from their ambient language was the similarity in frequency of the predicted CV co-occurrence patterns in Quichua children and adults. This outcome raises the possibility that the child patterns were in part induced by the ambient language input. Let us consider this possibility in the context of available evidence from both children and languages. MacNeilage et al. (2000) analyzed $\mathrm{CV}$ co-occurrence patterns based on dictionary counts of 10 languages. They found that the most characteristic co-occurrence patterns in languages that were predicted from the frame dominance hypothesis were also present in children. However, the mean levels of these patterns were lower in languages than in children's output. The mean levels of the three patterns across the 10 languages were 1.10 for labial-central, 1.18 for coronal-front, and 1.27 for dorsal-back. Above-chance occurrences in the 10 individual languages were 7 languages for 
labial-central, 7 languages for coronal-front, and 8 languages for dorsal-back. No other potential CV co-occurrence type showed an overall tendency to be substantially above chance levels. Roussett (2003) also found that the three cooccurrence patterns predicted for children were present in her study of 15 diverse languages. The mean levels observed were very similar to those found by MacNeilage et al. (2000). They were 1.08 for labial-central, 1.14 for coronalfront, and 1.18 for dorsal-back. Roussett (2003) also replicated the finding that no other potential CV co-occurrence type occurred at above-chance levels. Because of the frequency of predicted co-occurrence patterns in many languages studied, the similarities between CV co-occurrence patterns in both Quichua adults and children most clearly suggests universal production patterns based on optimal use of the production system for linguistic contrast.

Young children begin the babbling period evidencing these patterns and mature users of languages retain them in the face of dramatic expansion of phonological complexity in other aspects of phonological patterning across languages. This type of outcome suggests production system patterning rather than ambient language influence. To suggest ambient language influence, children in a language that has not retained the $\mathrm{CV}$ co-occurrences would have to be shown to stop using the patterns after an early period of showing the strong trends, thus exhibiting learning from their unique ambient language regularities. There also seems to be very little change in the syllabic constraints during the time period studied, with no significant changes in either within- or across-syllable patterns in the Quichua children between 9 and 22 months of age.

In the current study, no predicted CV co-occurrence pattern was observed in the American English adult data. These differences may perhaps be best explained by the use of conversational data rather than dictionary counts, which was used in previous studies. As noted earlier, dictionary counts provide co-occurrences that exist in individual words; however, it is not surprising that conversational samples differ from dictionary counts because of the repetition of high frequency words, which increases the frequency with which children hear words with nonpredicted CV co-occurrences.

In contrast to the dictionary counts by MacNeilage et al. (2000), in which the three within-syllable patterns were characteristic but not always present in English, evidence accumulated in children suggests that the occurrence of the three predicted co-occurrence patterns in children may be universal, or virtually universal, and not just characteristic. In addition, MacNeilage and colleagues (2000) found that the preference levels in children tend to be higher than those observed in languages.

As would be expected from these considerations, there are occasions in which children produce the patterns when they are not present in the ambient language. One example is the labial-central effect in English. This co-occurrence was found at below-chance levels in both the MacNeilage et al. (2000) dictionary count and in the analysis of English adult conversational samples. Yet it has repeatedly been observed in children in the English language environment. This type of result indicates that the labial-central $\mathrm{CV}$ co-occurrence may be a site where languages have introduced diversity. This option may be based on the lack of tongue engagement for the labial consonant portion of the syllable, leaving the 
production system with options for variation in mature speakers. This relative freedom of tongue engagement compared with the lingual engagement in the dorsal and coronal cases, allows for more variegation in the labial-vowel associations. Quichua, with only three vowels and a reliance on word length for diversifying vocabulary, may not depend on syllabic complexity to attain perceptual distinctiveness to the same extent as some other languages. Mandarin also has three vowels, but is made of almost exclusively of single-syllable words. Chen and Kent (2000) found predicted dorsal consonant-back vowel co-occurrences in Mandarin adults, but equal frequencies of coronal-front and coronal-back co-occurrences, and a nonpredicted labial-back vowel pattern (although they considered the /a/ of Mandarin a low-back vowel; in our study, we consider /a/ a low central vowel). It would be interesting to determine if other languages with small vowel inventories also show frame dominance predicted $\mathrm{CV}$ co-occurrence patterns in adults.

More convincing evidence relative to ambient language influences in withinsyllable patterning comes from Korean (Lee et al., 2007). Of the three co-occurrence patterns predicted for children, only coronal-front vowel cooccurrences were found to be significant in Korean child-directed speech; no significant co-occurrence patterns were found in Korean adult-directed speech. Yet all three patterns were found in Korean infant babbling output. Levels of labial-central and dorsal-back patterns, which were not favored in the language, were higher in babbling than in the first words of the Korean children. This decrease in the first word period suggests that ambient language input is contributing to the elimination of these preferences in Korean children by the onset of their first words. These findings suggest that the three within-syllable patterns are indeed inherent in child production system propensities and do not have to be preferred in the ambient language in order to be present in babbling. However, in cases such as Quichua, where a given co-occurrence pattern has a relatively strong presence in the ambient language, its presence suggests both the pattern's universality and the likelihood that the pattern will be produced by the children based on production system propensities common to young human children. Unlike the Korean children, the Quichua children are not faced with a learning task to match the patterns of their ambient language; they are matching that property from the onset of babbling.

One unpredicted CV co-occurrence pattern was found in English adults, in Quichua adults, and in Quichua children: a tendency for dorsal consonants to co-occur with central vowels. This co-occurrence pattern has also been reported for Italian children (Zmarich \& Lanni, 1999) and English and Swedish children (Boysson-Bardies, 1993), although not in other studies of babbling (Davis \& MacNeilage, 1995) and early speech (Davis et al., 2002) in English language environments. Its presence in both Quichua children and adults could be interpreted as an ambient language influence, as it has not generally been noted to occur across studies of children in other language communities. Perhaps the dorsal-central pattern, although not inherent, is readily available to children if it is present in the ambient language. It may result from consonants produced in the palatal region but transcribed as dorsals when they co-occur with unrounded central vowels. This interpretation seems likely, because many adult languages report the 
allophonic production of palatal for velar stops when abutted by relatively front vowels (Ladefoged, 2006). The possibility should be evaluated in an acoustical study across varied languages where the alternative CV co-occurrence pattern is found.

\section{CONCLUSION}

The consistency of findings in Quichua relative to other languages studied to date provides further support for the importance of production factors in understanding the nature of early speech acquisition across diverse languages. Quichua, and the Quechuan language family in general, are largely unstudied relative to the number of studies of English and other Indo-European languages. Many of the within-syllable patterns predicted by the frame dominance hypothesis and observed in Quichua- and English-learning child utterances also occurred in their ambient language, although not to the same extent as in the children. Frame dominance may weaken in adult language as the need for perceptual distinctiveness grows, resulting in a diversification of syllable shapes, especially in labial contexts.

Based on the parallel findings in children and adults, this study supports the notion of the frame, in the form of CV co-occurrence patterns and across-syllable sequences, as a basic organizational factor in humans producing serial output. These data on a typologically diverse language support the assertion that productionbased factors are a principle underlying factor in babbling. The production system provides a pattern that is largely retained by adult speakers in modern languages. The importance of production output factors has not been emphasized in contemporary psycholinguistic models. These models often emphasize perceptual processing in the mental instantiation of phonological knowledge (e.g., Swingley, 2008; Yoshida, Fennell, Swingley, \& Werker, 2009). The strength of the current findings suggests the importance of considering production factors to achieve a comprehensive understanding of children's acquisition of the phonological component of language.

\section{ACKNOWLEDGMENTS}

This work would not have been possible without the support of the children's families and the Salesian priests of Michacalá and Zumbagua. Data collection and reliability analyses were supported by many people, including Daniel Guanutuña, Marleen Haboud Ortega, Fernando Miño-Garcés, and Fabian Potosí in Ecuador, and Kathy Jakielski and Melissa Redford in the United States. Statistical analysis was possible with the assistance of Doug Neeley. Funding for data collection and analysis was provided by a Tinker Foundation Field Research Grant, Institute for Latin American Studies, University of Texas, Austin, and an International Education Fees Scholarship, International Education Office, University of Texas, Austin (both to C.G.-N.); and Department of Education Leadership Training Grant H325D000029 awarded to Thomas Marquardt, University of Texas, Austin. Support for collection and analysis of English child data was provided by NICHD Grant R-01 HD27733-07 (to B.L.D. and P.F.M.). 
Gildersleeve-Neumann et al.: Syllabic patterns in Quichua children

\section{NOTE}

1. To determine expected variegation frequencies cross-linguistically, actual occurrence of total reduplication, consonant manner (or vowel height) variegation, consonant place (or vowel backness) variegation, and total variegation were determined. Expected occurrence was determined after excluding examples of total reduplication and variegation. Because proportions tend to follow a binomial distribution and variances would not be expected to be homogeneous, weighted generalized linear modeling was used, specifying a log transformation of proportions and a binomial distribution. Observed and expected log-transformed proportions were adjusted for children within culture by including an indicator variable for each. A contrast variable was used that subtracted the log of the expected proportion from the log of observed proportion over children. The weight applied to the observed proportion was also applied to the expected proportion for a given baby. Two models were analyzed and compared: Model 1, which included baby indicator variables and a single contrast variable for comparing observed to expected proportions ignoring cultures, and Model 2, which also included child indicator variables but included two contrast variables for comparing observed to expected proportions, one each for the babies from the English- and the Quichua-speaking environments. The statistical difference formed the basis of testing the hypothesis that cultures differed in the tested measures. This method is analogous to an analysis of variance in which the deviance (analogous to sums of squares in an analysis of variance) from the Model 2 was subtracted from that in Model 1; an analogous difference is computed for degrees of freedom. Mean deviances (analogous to mean squares in an analysis of variance) were computed by dividing deviances by their associated degrees of freedom. The mean deviance associated with the difference in the models was divided by the residual mean deviance associated with Model 2, creating an $F$ statistic.

\section{REFERENCES}

Acevedo, M. A. 1993). Development of Spanish consonants in preschool children. Journal of Childhood Communication Disorders, 15, 9-15.

Boysson-Bardies, B. (1993). Ontogeny of language-specific syllabic productions. In B. BoyssonBardies, D. S. Schonen, P. Jusczyk, P. MacNeilage, \& J. Morton (Eds.), Developmental neurocognition: Speech and face processing in the first year of life (pp. 353-363). Dordrecht: Kluwer.

Boysson-Bardies, B., \& Vihman, M. (1991). Adaptation to language: Evidence from babbling and first words in four languages. Language, 67, 297-319.

Bush, C. N., Edwards, M. L., Luckau, J. M., Stoel, C. M., Macken, M. A., \& Peterson, J. D. (1973). On specifying a system for transcribing consonants in child language. Stanford, CA: Stanford University, Stanford Child Language Project.

Cerrón-Palomino, R. (1987). Lingüística Quechua. Cuzco, Perú: Centro de Estudios Rurales Andinos "Bartolomé de las Casas."

Chen, L., \& Kent, R. D. (2005). Consonant-vowel co-occurrence patterns in Mandarin-learning infants. Journal of Child Language, 32, 507-534.

Davis, B. L., \& MacNeilage, P. F. (1990). The acquisition of vowels: a case study. Journal of Speech and Hearing Research, 33, 16-27.

Davis, B. L., \& MacNeilage, P. F. (1994). Organization of babbling: A case study. Language and Speech, 37, 341-355.

Davis, B. L., \& MacNeilage, P. F. (1995). The articulatory basis of babbling. Journal of Speech and Hearing Research, 38, 1199-1211. 
Gildersleeve-Neumann et al.: Syllabic patterns in Quichua children

Davis, B. L., MacNeilage, P. F., \& Matyear, C. L. (2002). Acquisition of serial complexity in speech production: A comparison of phonetic and phonological approaches to first word production. Phonetica, 59, 75-107.

Dolata, J. K., Davis, B. L., \& MacNeilage, P. F. (2008). Characteristics of the rhythmic organization of babbling: Implications for an amodal linguistic rhythm. Infant Behavior and Development, $31,422-431$.

Garcés, L. F. (1996). Notas sobre la fonología del quichua ecuatoriano. Quito, Ecuador: Universidad Politécnica Salesiana.

Gildersleeve-Neumann, C. E., Davis, B. L., \& MacNeilage, P. F. (2000). Contingencies governing the production of fricatives, affricates, and liquids in babbling. Applied Psycholinguistics, 21, 341-363.

Hess, C. G. (1992). La racionalidad de una economía agropecuaria. Quito, Ecuador: Abya Yala.

Jakielski, K. J. (1998). Motor organization in the acquisition of consonant clusters. Unpublished doctoral dissertation. University of Texas, Austin.

Kent, R. D., \& Bauer, H. R. (1985). Vocalizations of one year olds. Journal of Child Language, 12, 491-526.

Kern, S., \& Davis, B. L. (2009). Emergent complexity in early vocal acquisition: Cross-linguistic comparisons of canonical babbling. In I. Chitoran, C. Coupé, E. Marsico, \& F. Pellegrino, (Eds.), (Approaches to phonological complexity, phonology and phonetics series (pp. 353376). Berlin: Mouton de Gruyter.

Kern, S., Davis, B., \& Zink, I. (2009). From babbling to first words in four languages: Common trends, cross language and individual differences. In J. M. Hombert \& F. d'Errico (Eds.), Becoming eloquent (pp. 205-232). Cambridge: John Benjamins.

Ladefoged, P. (2006). A course in phonetics (5th ed.). Fort Worth, TX: Harcourt College Javanovich.

Lee, S., Davis, B. L., \& MacNeilage, P. F. (2007). "Frame dominance" and the serial organization of babbling and first words in Korean-learning infants. Phonetic, 64, 217-236.

Lee, S., Davis, B. L., \& MacNeilage, P. F. (2008). Segmental properties of input to infants: A study of Korean. Journal of Child Language, 35, 591-617.

Lee, S., Davis, B. L., \& MacNeilage, P. F. (2009). Universal production patterns and ambient language influences in babbling: A cross-linguistic study of Korean- and English-learning infants. Journal of Child Language, 37, 293-318.

Locke, J. L. (1983). Phonological acquisition and change. New York: Academic Press.

Lombeida-Naranjo, E. B. (1976). Ecuadorean highland Quechua phonology. Unpublished doctoral dissertation. University of Texas, Austin.

MacNeilage, P. F., \& Davis, B. L. (1990). Acquisition of speech production: The achievement of segmental independence. In W. J. Hardcastle \& A. Marchal (Eds.), Speech production and speech modelling (pp. 55-66). Dordrecht: Kluwer.

MacNeilage, P. F., \& Davis, B. L. (1999). Evolution of the form of spoken words. Evolution of Communication, 3, 3-20.

MacNeilage, P. F., \& Davis, B. L. (2000). On the origin of internal structure of word forms. Science, 288, 527-531.

MacNeilage, P. F., Davis, B. L., Kinney, A., \& Matyear, C. L. (2000). The motor core of speech: A comparison of serial organization patterns in infants and languages. Child Development, 71, 153-163.

Maddieson, I. (1984). Patterns of sounds. Cambridge: Cambridge University Press.

Masaquiza, F. C., \& Marlett, S. A. (2008). Salasaca Quichua. Journal of the International Phonetic Association, 38, 223-227.

McCullagh, O., \& Nelder, J. A. (1989). Generalized linear models (2nd ed.). London: Chapman \& Hall.

Menard, L., Schwartz, J.-L., Boe, L.-J., \& Aubin, J. (2006). Articulatory-acoustic relationships during vocal tract growth for French vowels: Analysis of real data and simulations with an articulatory model. Journal of Phonetics, 35, 1-19.

Mitchell, P. R., \& Kent, R. D. (1990). Phonetic variation in multisyllabic babbling. Journal of Child Language, 17, 247-265.

Moya, R. (1987). Principios de lingüística quichua (Vol. 5). Quito, Ecuador: Centro de documentación e información de los movimientos sociales del Ecuador (CEDIME). 
Gildersleeve-Neumann et al.: Syllabic patterns in Quichua children

Nathani, S., Ertmer, D. J., \& Stark, R. E. (2006). Assessing vocal development in infants and toddlers. Clinical Linguistics and Phonetics, 20, 351-369.

Oller, D. K., \& Delgado, R. (2000). Logical International Phonetics Program (Version 2.02) [Computer software]. Miami, FL: Intelligent Hearing Systems.

Oller, D. K. (2000). The emergence of the speech capacity. Mahwah, NJ: Erlbaum.

Oller, D. K., \& Eilers, R. E. (1982). Similarity of babbling in Spanish- and English-learning babies. Journal of Child Language, 9, 565-577.

Oller, D. K., \& Lynch, M. P. (1992). Child vocalizations \& innovations in infraphonology: Toward a broader theory of development and disorders. In C. A. Ferguson, L. Menn, \& C. Stoel-Gammon (Eds.), Phonological development: Models, research, implications (pp. 509-536). Timonium, MD: York Press.

Oller, D. K., \& Steffans, M. L. (1993). Syllables and segments in child vocalizations and young child speech. In M. M. Yavas (Ed.), First and second language phonology (pp. 45-62). San Diego, CA: Singular Press.

Orr, C. (1978). Dialectos quichua del Ecuador (Vol. 2). Quito, Ecuador: Instituto Lingüístico de Verano.

Porter, J. H., \& Hodson, B. W. (2001). Collaborating to obtain phonological acquisition data for local schools. Language, Speech, \& Hearing Services in the Schools, 32, 162-171.

Redford, M. A., MacNeilage, P. F., \& Davis, B. L. (1997). Perceptual and motor influences on final consonant inventories in babbling. Phonetica, 54, 172-186.

Rousset, I. (2003). From lexical to syllabic organization: Favored and disfavored co-occurrences. Paper presented at the 15th International Congress of Phonetics, Autonomous University of Barcelona.

Rvachew, S., Alhaidary, A., Mattock, K., \& Polka, L. (2008). Emergence of the corner vowels in the babble produced by infants exposed to Canadian English or Canadian French. Journal of Phonetics, 36, 564-577.

Saffran, J. R., Aslin, R. N., \& Newport, E. L. (1996). Statistical learning by 8 month old infants. Science, 274, 1926-1928.

Smit, A., Hand, L., Frelinger, J., Bernthal, J., \& Byrd, A. (1990). The Iowa articulation norms project and its Nebraska replication. Journal of Speech and Hearing Disorders, 55, 779-798.

Stoel-Gammon, C. (1985). Phonetic inventories, 15-24 months: A longitudinal study. Journal of Speech and Hearing Research, 28, 505-512.

Swingley, D. (2008). The roots of the early vocabulary in infants' learning from speech. Psychological Science, 17, 308-312.

Torero, A. (1972). Lingüística e historia de la sociedad andina. In A. Escobar (Ed.), El reto del multilingüismo en el Perú (pp. 51-106). Lima: IEP.

Torero, A. (1983). La familia lingüística quechua. In B. Pottier (Ed.), America latina en sus lenguas indígenas (pp. 61-92). Caracas: UNESCO-Monte Avila.

Vihman, M., Ferguson, C., \& Elbert, M. (1986). Phonological development from babbling to speech: Common tendencies and individual differences. Applied Psycholinguistics, 7, 3-40.

Vihman, M. M. (1992). Early syllables and the construction of phonology. In C. A. Ferguson, L. Menn, \& C. Stoel-Gammon (Eds.), Phonological development: Models, research, implications (pp. 393-421). Timonium, MD: York Press.

Vihman, M. M., \& McCune, L. (1994). When is a word a word? Journal of Child Language, 21, $517-542$.

Yoshida, K., Fennell, C., Swingley, D., \& Werker, J. F. (2009). Fourteen-month-old infants learn similar sounding words. Developmental Science, 12, 412-418.

Zmarich, C., \& Lanni, R. A. (1999). Phonetic and acoustic study of babbling in an Italian child. Paper presented at the 5th International Conference on Spoken Language Processing. 